\title{
Nadir Bir Eritema Nodusum Nedeni Olarak Epstein-Barr virüs: Bir Olgu Sunumu ve Literatür Taraması
}

\author{
A Rare Cause of Erythema Nodusum: Epstein-Barr virüs: A Case Report and \\ Review of the Literature

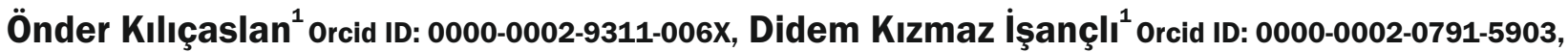 \\ Hatice Kübra Tülübaş ${ }^{1}$ Orcid ID: 0000-0002-8041-1293, Ömer YıImaz Ulutaş ${ }^{1}$ Orcid ID: 0000-0002-2814-6576,

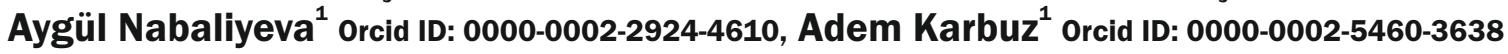 \\ ${ }^{1}$ Prof Dr Cemil Taşçıoğlu Şehir Hastanesi, Çocuk Enfeksiyon Kliniği, İstanbul, Türkiye.
}

Geliş Tarihi/Received: 10.05.2021

Kabul Tarihi/Accepted: 08.06.2021

Yazışma Adresi/Address for

Correspondence:

Önder Kılıçaslan

Prof. Dr. Cemil Taşçıŏlu Şehir

Hastanesi, Çocuk Enfeksiyon Kliniği,

İstanbul, Türkiye.

E-posta: dronderklcsIn@gmail.com

Anahtar Sözcükler:

Adolesan

Döküntü

Epstein-Barr Virüs

Eritema Nodosum

\section{Key Words:}

Adolescent

Epstein-Barr Virus

Erythema Nodosum

Rash

\begin{abstract}
öz
Eritema nodozum en yaygın septal pannikülit şeklidir. Vakaların \%50'sinde hiçbir neden bulunamaz. Tanımlanmış nedenlerin en önemlilerinden biri enfeksiyonlardır. EpsteinBarr virüs de nadir bir eritema nodozum nedenidir. On beş yaşında kız hasta bir gün süren ateş ve bacaklarda daha belirgin ağrılı kızarık lezyonlar nedeni ile acil servise başvurdu. Fizik muayenesinde ön kol iç yüzünde ve bacaklarda en büyüğü $3 \times 5 \mathrm{~cm}$ olan eritemli zemin üzerinde bulunan ağrılı nodüller dışında bulgu yoktu. Ön planda eritema nodozum düşünülen hasta servise yatırıldı. Yapılan tetkiklerden tam kan sayımı normal bulundu. Akut faz reaktanları yüksek bulunan hastanın alınan boğaz, idrar ve kan kültürlerinde üreme saptanmadı. Etiyolojiye yönelik yapılan mikrobiyolojik testlerden sadece anti-viral kapsid antijen (VCA)-IgM/IgG testi pozitif saptandı. Epstein-Barr virüse bağlı eritema nodozum tanısı alan hasta semptomatik tedavi ile takip edildi. Yatışının 8. gününde ağrısı ve lezyonları gerileyen hasta taburcu edildi. Epstein-Barr virüsün en sık cilt bulgusu makulopapüler döküntü olsa da eritema nodozum saptanan hastalarda akılda bulundurmalıdır.
\end{abstract}

\begin{abstract}
Erythema nodosum is the most common form of septal panniculitis. In $50 \%$ of cases, no cause can be found. Epstein-Barr virus is a rare cause of erythema nodosum. A fifteenyear-old girl presented to the emergency department with fever and painful hyperemic lesions more prominent on the legs. Physical examination revealed no pathological findings except of the painful nodules, on the forearm and legs, the largest of which was $3 \times 5 \mathrm{~cm}$. The patient was hospitalized with diagnose of erythema nodosum. Complete blood count was normal. Acute phase reactants were found elevated. Cultures were found negative. Only anti-viral capsid antigen-lgM/IgG tests were found to be positive. The patient was followed up with symptomatic treatment. The patient, whose pain and lesions regressed, was discharged (8th day). Although the most common skin manifestation of Epstein-Barr virus is maculopapular rash, Epstein-Barr virus should also be kept in mind when erythema nodosum is detected.
\end{abstract}

\section{Giriş}

Eritema nodozum (EN), herhangi bir antijene veya tetikleyiciye yanıt olarak meydana gelen aşırı duyarlılık reaksiyonu sonucu oluşan en yaygın septal pannikülit şeklidir. Aynı zamanda inflamatuvar nodüllerin de en sık nedenidir. Vakaların yaklaşık \%50'sinde hiçbir neden bulunamaz ve durumun idiyopatik olduğu kabul edilir. Tanımlanmış nedenlerin en önemlilerinden biri enfeksiyonlardır (1).
Epstein-Barr virüs (EBV); ateş, eksudatif farenjit, lenfadenopati, hepatosplenomegali ve atipik lenfositoz ile karakterize enfeksiyöz mononükleoza ve birçok sistemde etkilenmeye neden olabilecek bir virüstür (2). En sık meydana gelen cilt bulgusu makulopapüler döküntüdür. Daha seyrek olarak ise çocuklarda sıklıkla aksiller bölgeyi tutan tek taraflı laterotorasik ekzantem, "hedef" lezyonlar ve bol mukoz membran tutulumu ile karakterize Stevens-John- 
son sendromu, EN, eritema multiforme ve kriyoglobulinemi ile ilişkili soğuk ürtiker görülebilmektedir (3). Bu vakada; EBV'nin nadir bir cilt bulgusu olan EN ile başvurup tetkiklerinde EBV saptanan 15 yaşında bir olgu sunularak, EN etiyolojisinde EBV'nin de akılda bulundurulması gerektiği vurgulanmak istenmiştir.

\section{Olgu Sunumu}

On beş yaşında kız hasta ateş ve bacaklarda daha belirgin olmak üzere her iki ön kol ve bacak ön yüzde ortaya çıkan ağrılı ve kızarık lezyonlar nedeni ile acil servise başvurdu. Ateşinin bir gün önce başladığı, dirençli olmadığı, döküntülerin oluşmasıyla da hastaneye başvurduğu öğrenildi. Akut gastroenterit nedeniyle çocuk enfeksiyon servisinde 6 gün takip ve tedavisi yapılan hasta 5 gün önce taburcu olmuştu. Son 2 ay içinde çevresinde ateşli veya döküntülü hastalık geçiren biri ile teması yoktu. Evinde kedi beslediği öğrenilen hastanın özgeçmiş ve soy geçmişinde başka özelik saptanmadı. Fizik muayenesinde bilateral ön kol iç yüzünde ve bacak ön yüzünde en büyüğü $3 \times 5 \mathrm{~cm}$ olan eritemli zemin üzerinde bulunan ağrılı nodüller dışında patolojik bulgu yoktu (Şekil 1,2). Lezyonlar ilaç erüpsiyonu veya alerjik döküntü olarak değerlendirilmedi. Öncelikle EN düşünülen hasta ileri tetkik ve tedavi düzenIenmesi için servise yatırıldı. Tetkiklerinde hemoglobin değeri 12g/L, beyaz küre sayısı 14520uL, nötrofil sayısı $11880 u L$, lenfosit sayısı 1960uL, monosit sayısı 630uL, trombosit sayısı 362000uL, C Reaktif protein 104mg/L, sedimentasyon $125 \mathrm{~mm} / \mathrm{h}$ saptandı. Periferik yaymasında blast, atipik hücre veya downey hücresi görülmedi, ancak

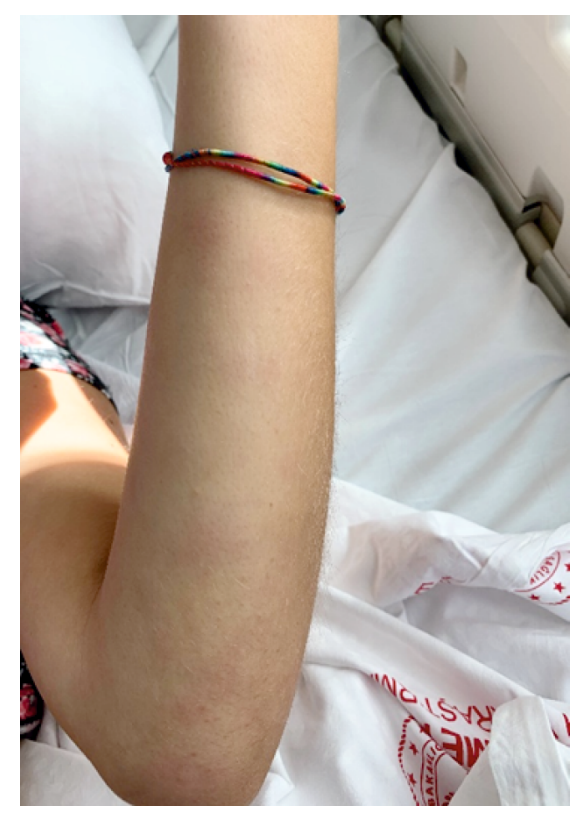

Şekil 1. Ön Kolda Bulunan Eritema Nodozum Lezyonları.

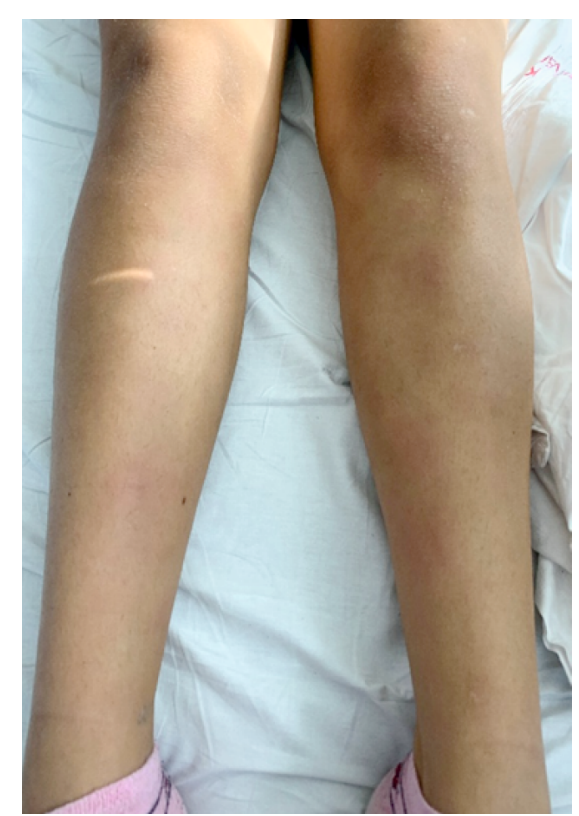

Şekil 2: Bacaklarda Bulunan Eritema Nodozum Lezyonları. viral enfeksiyon ile uyumlu olarak değerlendirildi. Böbrek ve karaciğer fonksiyon testleri, koagulasyon testleri ile tam idrar tetkiki (TiT) normal sınırlarda idi. Evinde bulunan kedi ile sık teması olması ve Bartonella Henselae ajanına yönelik spesifik test gönderilme imkanı olmadığı için ek bir fizik muayene bulgusu olmamasına da rağmen hastaya ampirik azitromisin tedavisi başlandı. Gaita mikroskopisinde özellik yoktu. Gaitada Rota, Adeno antijen testleri negatifti. İmmunglobulin (Ig) E ve IgG düzeyleri yaşına göre uygun seviyelerde idi. Anti nükleer antikor (ANA) ve Anti dsDNA negatif bulundu. Tüberküloz için yapılan PPD testi negatif olarak değerlendirildi. Spesifik mikrobiyolojik ajanlara yönelik yapılan incelemelerde; grup A streptokok (GAS) hızı antijen testi, Brucella tüp aglütinasyon testi ve Rose Bengal testi, HbsAg, Anti-HCV, Anti-HIV, Toxoplazma-IgM, Sitomegalovirüs (CMV)-IgM, Parvovirüs-lgM, Mycoplasma pneumoniae-lgM testleri negatif saptanırken EBV antiviral kapsid antijen (VCA)-IgM ve anti-VCA-IgG testi pozitif saptandı. Epstein-Barr nükleer antijeni (EBNA) antikorları ise negatif idi. Kan, boğaz, idrar ve gaita kültürlerinde üreme olmadı. Dirençli ateşi olmayan hastanın EBV enfeksiyonu saptanması nedeniyle azitromisin tedavisi 3. günde kesilerek semptomatik tedavi ile takip edildi. Batın ultrasonografi ve ekokardiyografi (EKO) normal olarak değerlendirildi. Göz muayenesinde patoloji saptanmadı. Hasta genel durumu ve beslenmesi iyi olması, lezyonlarının gerilemesi, ateşi ve ek şikâyeti olmaması nedeniyle yatışının 8. günü taburcu edildi. Olgu sunumu için hastadan bilgilendirilmiş onam alınmıştır.

\section{Tartışma}

Pannikülit, deri altı yağ dokusunun yama veya nodüller ile karakterize ani gelişen ve nadir görünen iltihaplanmasıdır. Eritema nodozum, pannikülitin en yaygın klinik sunumudur. Yılda yaklaşık 100.000 kişide 1-5 oranında görünür. En yüksek insidans 15-30 yaş arası genç kadınlarda olmakla birlikte bu yaş grubunda erkek/kadın oranı 1:6'dır. Çocuklarda ise cinsiyetler arası oran 1:1'dir (4). Hastamı 15 yaşında ve kız olup, EN'nin en yüksek insidansa sahip olduğu yaş aralığı ve cinsiyette idi.

Eritema nodozum tanısı klinik olarak konmaktadır. Genellikle pretibial bölgede ani başlayan ağrılı ve kızarık nodüller ile karakterizedir. Hastalığın 
tanısında kullanılan klinik kriterler; 1. Ağrılı, eritematöz veya mor renkte, nodüller veya yama şeklinde, genellikle 1$5 \mathrm{~cm}$ boyutunda, sınırları düzensiz ve belirsiz lezyonlar 2 . Simetrik tibial ön yüzeyde meydana gelen lezyonlar (diğer cilt alanlarına ulaşsın veya ulaşmasın) 3. Ani ortaya çıkan ve 8 haftadan kısa süren lezyonlar 4 . Ülserasyon veya yara izi olmaksızın gerileme (4). Lezyonların en sık yerleşim yeri tibial ön yüzeydir, ancak önkol, uyluk, göğüs ve hatta yüzü veya ekstansör yüzeyi de tutulabilir (5). Hastamızın tanısı klinik olarak, ani başlayan, hiperemik zemin üzerinde, en büyüğü yaklaşık $3 \times 5 \mathrm{~cm}$ olan, bilateral alt ekstremite ön yüzlerde daha belirgin olmakla birlikte ön kolda da bulunan ağrılı nodüllerin bulunması ile konuldu.

Kapsamlı araştırmalara rağmen EN'li hastaların yarısında etiyolojik bir neden bulunamamaktadır (4). Tespit edilen nedenler arasında enfeksiyonlar, ilaçlar, aşılar, gebelik, inflamatuar barsak hastalıkları, sarkaidoz, otoimmun hastalıklar, paraneoplastik hastalıklar sayılabilir (1). Enfeksiyoz nedenler arasında en sık araştırılması gerekenler streptokokal enfeksiyonlar (GAS farenjit), tüberküloz, EBV, CMV, Varicella Zoster Virüs, Kabakulak başta olmak üzere salmonella, şhigella, mikoplazma gibi bakteriyel, hepatit A, B, C, HIV ve parvovirüs B19 gibi viral, Toxoplasma gondii, Ascaris lumbricoides, Entamoeba histolytica gibi paraziter, Aspergillus ve Candida albicans gibi mantar kaynaklı enfeksiyoz etkenler de araştırılmalıdır (6). Hastamızın akut faz reaktanları yüksek idi. Biyokimyası ve Tiт normaldi. Anamnezinde alerji veya ilaç erüpsiyonu düşündürecek özelik yoktu. Serum IgE düzeyi normal sınırlarda idi. Otoimmun hastalıklar açısından bakılan ANA ve Anti dsDNA negatif bulundu. Yakın zamanda gastroenterit nedeni ile yatış hikayesi olması sebebiyle bakılan eski ve yeni gaita tetkiklerinde (Rota antijen, Adeno antijen, gaita mikroskopisi, gaita kültürü) özelik saptanmadı. PPD testi negatif olarak değerlendirildi. EKO'da kardiyak patoloji saptanmadı. Boğaz, idrar ve kan kültüründe üreme olmadı. GAS hızlı antijen testi, Brucella tüp aglütinasyon testi ve Rose Bengal testi, HbsAg, Anti-HCV, Anti-HIV, Toxoplazma, CMV, Parvovirüs, Mycoplasma pneumoniae-lgM testleri negatif saptanırken, Anti-VCA-lgM ve IgG testleri pozitif, EBNA antikorları negatif saptandı. Böylece hastamızda ortaya çıkan EN'nin akut EBV'ye bağlı olduğunu tespit etmiş olduk.

Epstein-Barr virüs, insan popülasyonunun büyük bir bölümünü enfekte eden ve periferik kanda bulunan hafıza $B$ hücrelerinde latent formda kalan bir herpes virüsüdür. Gelişmiş ülkelerde, EBV enfeksiyonu prevalansı çocuklarda \%60-80'e ve erken yetişkinlik döneminde \%95'e yaklaşmaktadır (7). Yaygın görünmesinin en önemli nedeni yakın teması ile kolayca bulaşabilmesidir ve bu bulaşın büyük bir kısmını oluşturmaktadır. Diğer bulaşma yolları ise kan transfüzyonu, allograft transplantasyon, cinsel ilişki ve hane halkı veya bakıcı ile yakın temastır (8). EBV, bademcikler ve adenoidler gibi lenfoid dokulardaki $\mathrm{B}$ hücrelerini enfekte etmek için mukozal epitelden geçer ve 30-50 günlük inkübasyon süresi boyunca, viral replikasyon ve yayılma, lenforetiküler sistem yoluyla gerçekleşir (7). Hastamızın son 2 ay içinde yakın çevresinde ateşli, döküntülü hastalık geçiren biri ile teması yoktu.

Epstein-Barr virüs enfeksiyonları genellikle asemptomatik seyretmektedir. Eğer semptomatik ise ana belirtiler ateş, farenjit, lenfadenopati ve splenomegalidir. Ayrıca EBV; aseptik menenjit, ensefalit, miyelit, optik nörit, kraniyal sinir felci, transvers miyelit, Alice Harikalar Diyarında sendromu, Guillain-Barré sendromu gibi nörolojik belirtilere, dalak yırtılması, agranülositoz, hemolitik anemi ve hemofagositik lenfohistiyositoz (HLH) gibi hematolojik belirtilere neden olabilmektedir. Nadir olarak ta hastalarda pnömoni, orşit ve miyokardit görülebilir $(2,9)$. Hastamızda ateş ve eritema nodozum dışında klinik belirti yoktu. Göz muayenesi ve EKO normal olarak değerlendirildi. Organomegali saptanmadı.

Epstein-Barr virus'e bağlı cilt döküntüsü, genellikle ilk olarak gövde ve üst ekstremitelerde, ardından yüze ve ön kollara uzanan eritemli, makulopapüler bir döküntüdür. Bir haftaya kadar sürebilir. Varsayılan bakteriyel enfeksiyonu tedavi etmek için kullanılan penisilin (özellikle amoksisilin ve ampisilin), başlanmasından 7-10 gün sonra aşırı duyarlılık deri reaksiyonunun gelişmesine yol açabilir. Bu döküntü, ekstansör yüzeyler ve basınç noktaları üzerinde gelişen ve gövde ve ekstremitelere yayıldıkça birleşik hale gelen maküler bir döküntüdür (7). EBV'ye bağı nadir de olsa EN de görülebilmektedir (3). Bizim de hastamızda EBV'nin sık görünen deri bulgularından ziyade nadir bir cilt bulgusu olan EN saptandı.

Epstein-Barr virüs'ünün tanısında klinik bulgular yanında laboratuvar tetkiklerinden faydalanılmaktadır. Hemogramda anemi, lökopeni, trombositopeni görülebilmektedir. Ancak lenfositoz ve monositoz daha sık bulunmaktadır. Periferik yaymada atipik lenfositlerin \%10 ve üzerinde saptanması önemli bir destekleyici bulgudur (10). EBV enfeksiyonu tanısı için en yaygın kullanılan test, VCA'ya karşı gelişen antikor düzeylerinin saptanmasıdır. Enfeksiyonun erken dönemlerinde anti-VCA-lgG yüksek titrede ortaya çıktığından ve yaşam boyu orta düzeylerde kaldığından, tek başına aktif enfeksiyonun varlığını belirlemek için yararlı değildir. Bunun tersine, anti-VCA-IgM antikorunun tespit edilmesi, aktif ve yeni enfeksiyonları tanımlamak için yararlıdır. EBNA'ya karşı gelişen antikorlar ise enfeksiyo- 
nun başlangııından belirli bir süre geçmesi ile ortaya çıkmaktadır. Anti-VCA-IgM pozitif ve EBNA antikorunun negatif saptanması kuvvetle akut EBV enfeksiyonunu düşündürmektedir. Aksine çok yüksek EBNA antikor düzeyleri aktif enfeksiyonu dışlayabilmektedir $(2,9)$. Hastamızda anti-VCA-IgM ve anti-VCA-IgG pozitif olarak saptanırken EBNA antikoru ise negatif bulundu. Hematolojik parametrelerde anomali yoktu. Ancak periferik yayma viral enfeksiyon ile uyumlu saptandı.

Çoğu EN vakası kendi kendini sınırlar ve dikkatli gözlem dışında hiçbir tedavi gerektirmez. Tedavi esas olarak semptomatiktir. Rahatsızlığı azaltmak için genellikle yatak istirahati ve bacak kaldırma önerilir. Steroid olmayan antiinflamatuvar ilaçlar (örn. ibuprofen, naproksen, indometasin) ağrı tedavisinde ilk seçenek tedavidir. Pediatrik yaş grubunda asetilsalisilik asit kullanımından kaçınılmalıdır. Sistemik kortikosteroidler, ağrının azaltılmasında ve lezyonların çözülmesinde hızlı bir şekilde

Yazarlık katkısı: Fikir/Hipotez: ÖK, DKI, HKT, ÖYU, AN, AK. Tasarım: ÖK, DKI, HKT, ÖYU, AN, AK. Veri toplama/Veri işleme: ÖK, DKi, HKT, ÖYU, AN, AK. Veri analizi: YB. Makalenin hazırlanması: HKT, ÖYU, AN. Makalenin kontrolü: ÖK, DKI, AK.

\section{Etik Kurul Onayı: Gerekli değildir.}

Hasta Onayı: Olgu sunumu için hastadan izin alınmıştır.

\section{Kaynaklar}

1. Leung AKC, Leong KF, Lam JM. Erythema nodosum. World J Pediatr 2018;14:548-554.

2. Epstein-Barr Virus Infections. In: Carol J. Baker, editor. Red Book Atlas of Pediatric Infectious Diseases. 4th Edition. American Academy of Pediatrics 2020:196-198.

3. Ciccarese G, Trave I, Herzum A, Parodi A, Drago F. Dermatological manifestations of Epstein-Barr virus systemic infection: a case report and literature review. Int J Dermatol 2020;59: 1202-1209.

4. Sartori DS, Mombelli L, Sartori NS. Erythema Nodosum. In: R.R. Bonamigo, S.I.T. Dornelles editors. Dermatology in Public Health Environments. 1st Edition. Switzerland: Springer International Publishing 2018:1339-1348.

5. Schwartz RA, Nervi SJ. Erythema nodosum: a sign of systemic disease. Am Fam Physician 2007;75:695-700. etkili olabilir ve şiddetli vakalarda düşünülebilir ancak kullanılmadan önce tüberküloz gibi bulaşıcı nedenler dışlanmalıdır $(1,11)$. EBV'de de tedavi genellikle semptomatiktir. Kısa süreli kortikosteroidler ile yapılan tedavinin bazı akut semptomlar üzerinde yararlı bir etkisi olabilmesine rağmen, potansiyel yan etkiler nedeniyle, kullanımı yalnızca; hava yolu obstrüksiyonu muhtemel belirgin tonsiller iltihabı olan hastalar, masif splenomegali, miyokardit, hemolitik anemi veya HLH ile birlikte olan hastalar için düşünülmelidir (2). Hastamızda tanının EBV lehine sonuçlanması nedeniyle mevcut antibiyotik tedavisi kesilerek analjezik ile izlendi ve yatışının 8. gününde lezyonları gerilemesi üzerine hasta taburcu edildi.

Epstein-Barr virüs ve EN birlikteliği nadir görülen bir durumdur. Biz de bu olgu ile EBV'nin nadir bir cilt bulgusu olan EN'li 15 yaşında bir hastayı sunarak Türk literatürüne bir katkıda bulunmak istedik.

Hakem Değerlendirmesi: İlgili alan editörü tarafından atanan iki farklı kurumda çalışan bağımsız hakemler tarafından değerlendirilmiştir.

Çıkar Çatışması: Yazarlar tarafından çıkar çatışması bildirilmemiştir.

Finansal Destek: Yazarlar tarafından finansal destek almadıkları bildirilmiştir.

6. Chowaniec M, Starba A, Wiland P. Erythema nodosum-review of the literature. Reumatologia 2016;54:79-82.

7. Lernia DV, Mansouri Y. Epstein-Barr virus and skin manifestations in childhood. Int J Dermatol 2013;52:1177-1184.

8. Dunmire SK, Verghese PS, Balfour HH. Primary Epstein-Barr virus infection. J Clin Virol 2018;102:84-92.

9. Gümüşer F. 0-18 Yaş Grubunda Epstein-Barr Virüsü (EBV)'nün Serolojik Tanısında ELISA ve IFA Testlerinin Karşılaştırılması. FLORA 2018;23:102-107.

10. Ardıç E, Karaali R, Yağmur O, ve ark. A case of acute cholestatic hepatitis due to Epstein-Barr virus infection. Klimik Derg 2020;33:100-102.

11. Blake T, Manahan M, Rodins K. Erythema nodosum-a review of an uncommon panniculitis. Dermatol Online J 2014;20: 22376. 